\title{
Franz Klein, Mauro Cappelletti, and the mission of comparative procedural scholars: opening lecture for International Association of Procedural Law ${ }^{1}$
}

Bryant Garth

One hundred years ago, at the time of Vienna's preceding fin de siecle, the famous Austrian Code of Civil Procedure of 1895 was drafted by Franz Klein, a professor working for the Ministry of Justice. This landmark of civil procedure is appropriately celebrated at this Vienna Congress. Almost every procedural scholar, in addition, knows Kelein's famous statement about civil procedure, made in 1901:

"The squalid, arid, neglected phenomenon of civil procedure is in fact strictly connected with the great intellectual movement of people, and its varied manifestations are among the most important documents of mankind's culture».

[(Quoted by Mauro Cappelletti in Social and Political Aspects of Civil Procedure-Reforms and Trends in Western and Eastern Europe. 69 Mich. Rev. 847, 885-6 (1971)]

We might think about this quotation in the context of Vienna at the dawn of a new century. Note that Klein was somewhat defensive, suggesting civil procedure was neglected, considered even arid. Law graduates at that time dominated the Viennese state and bureaucracy, but I doubt if the courts were considered to be leading instruments of reform. Law was under some attack. Economics was developing as a challenging cousin, led by Carl Menger, the brother of one of Klein's

1 Opening lecture XI World Congress of International Association of Procedural Law (LAPL); Vienna, Austria, August 24, 1999. 
famous professors. Sigmund Freud, who at the last minute decided to reject his father's advice and go toward a career in science rather than law, published his Interpretation of Dreams in 1900. Freud challenged the rational authority that law and his father represented. Gustav Klimpt in 1901 painted his work entitled «Jurisprudence», which portrays law as a hellish power that, according to one analyst, «only screens and legitimate violence" (Carl Schorke, Fin de Siecle Vienna, 1980. p. 251). Law's position as engine of progress was far from taken for granted. At best, it was hardly relevant, but more likely law and lawyers were considered obstacles to progress. Klein and his reform sought to align law and its procedures with the progress of the social welfare state.

Subsequent political developments suggest that law certainly did not stay at the core of political and intellectual developments in Austria. Nevertheless, what is interesting is that the Code of Civil Procedure that Klein produced sought to find a place for progressive law in the midst of these challenges. Law was not to be an obstacle to social justice and social peace, but rather was supposed to be an instrument that, through the enlightened colloquies undertaken between judges and litigants, would bring social peace and facilitate a welfare state (See A. Homberger, «Functions of Orality in Austrian and American Civil Procedure», Buffalo Law Review, (1970). The active judge envisioned by Klein would go perfectly with the active state. The Austrian Code became the inspiration for procedural reforms in civil law systems (and even beyond) around the world. It was the culmination of the efforts toward "orality", «inmediacy», and "the concentration of the proceedings". It could be invoked consistently in Europe especially in the period after World War II.

The developments promoted by Klein have strong parallels in the movement for social change in the 1960's and 1970's. Again, it was an intense period of social movements, welfare states, and challenges to law by a powerful state and by relatively new disciplines such as, again, economics, but also sociology and political science. Once again, relatively few non-legal scholars in the civil law world would have though that law was a key to keeping the society in motion. This was certainly true in Italy, which was dominated by a complex process of political bargaining. Mauro Cappelletti, as an Italian proceduralist, had to redefine the role of procedure in such a setting. 
I met Mauro Cappelletti, former President of this Association, in 1975, when I graduated from law school and went to work on his "Access to Justice" project, which was just getting underway in Florence. One of the first things I learned working for him was that he had a kind of favorite procedural quotation, which was the quote from Franz Klein mentioned before. Again, it was not just a quotation for Cappelletti, but rather a problem that defined his career. He believed that civil procedure should be strictly connected with great intellectual movements and, as indicated clearly by as an article he published in 1971 that quoted Klein, insisted that procedure should be closely connected to politics and society. Civil procedure, in other words, should be involved in the social change activity then taking place.

Cappelletti's vision was not free from controversy. The problem was both internal to the field of civil procedure in Italy and outside among those skeptical that procedural law -or even the law generally- mattered. Within the field Cappelletti attacked those who, in his opinion, assured themselves and the law a marginal position by dealing only with formalistic and technical minutiae derived from the classic treatises and codes of civil procedure. Klein's code was revered, but the political and intellectual inspiration that produced it had been forgotten. Cappelletti himself, of course, had to master this careful but, in his opinion, unimaginative approach in order to gain a chair in civil procedure in Italy. His attack on that system brought costs to himself and his students, but he kept fighting. This organization, the International Association of Procedural Law was revived in part to continue that fight.

How did Mauro Cappelletti approach this problem of the place of law and especially comparative civil procedure? He took the radical step of looking outside the civil law world to the United States, where law and procedure had come to play a key role in the welfare state and social movements such as the civil rights struggle. To oversimplify, he would undertake projects that would relate legal developments in the United States to what were often inchoate or fragmentary developments in Europe (and outside) and distill models based on those experiences. The comparison would highlight new possibilities for procedural law, especially in Europe. Examples could be multiplied, but it will suffice to mention judicial review, legal aid, class actions and organizational lawsuits, access to justice, alternative dispute resolution, and federalism. 
Needless to say, these topics from outside the treatises and codes of procedure reshaped the agenda of civil procedure. As Cappelletti hoped, it brought civil procedure much closer to the great intellectual and social movements of the time. Cappelletti made procedural scholars proud of their field. He also brought in legal sociologists who would situate these "procedural" developments in larger social contexts and describe just how they worked in practice. Cappelletti always sought data and empirical study, culminating in the detailed empirical studies in the Access-to-Justice volumes.

A key ingredient in his approach was the development of comparative models: centralized vs. decentralized judicial review; governmental attorneys general vs. class actions vs. standing to state-approved organizations; judicare vs. staff legal aid; U.S. vs. Europe. He could use the models to produce ideas or reforms that, whether promoting the usually extreme U.S. model or the "civilized" counterpart, would have the effect of making law and comparative procedure far more engaged with important social concerns. Indeed, procedural scholars could build the field by debating what models might successfully be transplanted. Civil law solutions, including those derived from Austrian models of procedure, were always possible and visible. Indeed, the careful comparisons fed back into U.S. debates, helping to keep U.S. scholars less parochial and more aware of U.S. eccentricities. There are many cases where Cappelletti's models and comparisons made possible the enactment of reforms that achieved what he wanted in terms of the role of procedure.

Let us now move to the present. What is the challenge today for the Klein-Cappelletti vision? It is no longer a way to reconcile the «liberal" law with "modern welfare states". The "third way" today is not between capitalism and socialism, but rather represents some variant of liberal market democracy. Economists came to power in the 1970s and 1980s and restricted the role of activist states. Socialism has died, and the phenomenon (and marketing of) «globalization» is changing what law and states are. Indeed, there are countless state-like actors above, under, and around the states that lawyers are discovering and legitimating. What do these processes mean for comparative civil procedure?

A brief story might help. In the early 1990 s, several of us -including Marcel Storme and me- were invited to Argentina to consult about a World Bank project of court reform. I agreed to visit Argentina not because I thought I could tell the Argentines anything more than they 
already knew, but I thought I could promote the work of the scholars I already knew and respected. While I was there, I kept getting asked about U.S. -style ADR (Alternative Dispute Resolution). I wrote a report for the World Bank that spoke of the civil procedure tradition on the Continent, including the legacy of Klein and what could be learned in procedural reform from the people here at this Vienna Congress. The major Argentine procedural reform so far, however, is mandatory mediation taken explicitly from the United States and its industry of «ADR». These reforms were produced less by comparative study and more by reformerentrepreneurs who used non-profit foundations, political contacts, contacts with U.S. entrepreneurs, and the prestige of U.S. institutions to promote this change. The reform may be very successful. The point, however, is that we see a very different process and approach than what Cappelletti encouraged and fostered. Instead of processes of comparative procedural reform, systematic study, and different models of practice that could make law relevant to today's concerns, we see a market of entrepreneurial reformers dominated by the United States. It is almost like purchasing reforms from a menu of U.S. options. The Argentine story is not unusual.

It is worth exploring the contrasting approaches. Instead of bridging gaps between civil law and common law, especially the U.S., civil law models have become increasingly marginal. They are not built systematically into the serious options. Another example of this market process of legal transformation is international commercial arbitration, which twenty years ago was an informal process characterized by procedures that were probably relatively close to what Klein sought ${ }^{2}$. It has subtly become Americanized, not by "choice" but because of the influence of the United States and U.S. trained lawyer who believe that the legal weapons they have learned to use represent not historical products of the U.S., but rather fundamentals essential to fair civil procedure. Many of the same lawyers now argue that, since arbitration has become more expensive, contested, and U.S. like, the only remedy is ADR U.S. -style. This is not a conspiracy, but a process that repeats itself through illinformed markets that tend to lead to products made in the U.S.A.

2 We discuss the changes in international commercial arbitration in Yves Dezalay and Bryant Garth, Dealing in Virtue: International Commercial Arbitration and the Construction of a Transnational legal Order (University of Chicago, 1996). 
Because so much of what happens is outside of national court systems, in addition, even the processes of change are difficult to understand. It is no longer about deep comparative study by academic experts shielded from politics and power by a Ministry of Justice. It is a wide-open free for all where there is no guarantee at all that the relevant expertise will in fact be heard. One danger, therefore, is that procedural reform will simply follow a market that substitutes prestige, hierarchy, and notoriety for deep investigation and comparison.

The related danger is that procedural scholars finding themselves not in demand will simply retreat. They can be comfortable and secure, after all, in what they do know, avoiding the systematic study and modeling that helped make sure that more than one model would be considered. Cappelletti to his credit saw the growing influence of the United States and tried to use it not only to make civil procedure more central, but also to produce detailed information that would promote what the civil law system had produced.

What should we do in the new context? Unfortunately, we no longer have Mauro Cappelletti's formidable brain and organizing skills to help us. One thing to do is to form alliances again with those who will critically study the processes of change. For example, I think, we could find that a source of the dominance of the U.S. (sometimes, AngloAmerican) approach is that there are now major corporate law firms modeled on U.S. law firms in the major cities of the world. The lawyers in these firms all speak the same legal language and promote similar legal approaches. But the U.S. institution of public interest law firm has not been a successful export. Do U.S. models work when only one-half of the model is adopted - the part that promotes a business law and practice?

Second, we might reassert the relevance of Klein and others in comparison to a U.S. approach that permits «scorched earth" litigation, open discovery that involves routine games to hide documents, depositions that often only take up time and raise the stakes for settlement negotiations, and in general litigation as a weapon in business competition. Comparativists should help provide some balance, especially since the negative aspects of U.S. models are typically forgotten when exports are contemplated. Following Cappelletti, in other words, we could argue again for a sophisticated pluralism of approaches - seeing the power of U.S. models without promoting them as universal solutions. 
Finally, comparative procedural scholars should invest more in the reform market. Mauro Cappelletti, while a learned scholar, was not afraid of entrepreneurial activity. If comparative civil procedure is to play a role in the global transformations that are all around us, we need to upgrade, expand, and reinvent our field. A key advantage of the U.S. approaches in the competitive marketplace of expertise is that U.S. legal scholars are themselves embedded in a very competitive legal world of scholarship. Instead of updating treatises or waiting for chairs to open in traditional legal domains, they must seek out new domains to gain attention. Just as European companies have had to change to compete effectively with the U.S., companies perhaps it is necessary to deregulate the academic market to encourage more innovations in civil procedure.

For what it is worth, I believe there are huge opportunities to bring procedural scholarship to bear on a new kind of law located around traditional private and public law. Procedures in these areas are of fundamental importance, but comparative proceduralists have not systemically addressed these domains.

The Worls Trade Organiztion, for example, is debating who should have standing and what if any role there should be for non-governmental organizations. Trade issues generally, including dispute resolution under NAFTA and more generally anti-dumping, involve important procedural issue including those relating to access. Global competition law will have similar issues, with new procedures and entities. Intellectual property and the WIPO dispute resolution machinery are also important emerging regimes with procedural issues. Similary, now that shareholder value is becoming the key to business strategies worldwide, what will happen with shareholder derivative suits worldwide? Mass torts are also becoming globalized. What should be done there? Other global domains that are not yet the subject of procedural scrutiny include the World Bank's Inspection Panels, which have jurisdiction to consider challenges to World Bank projects on environmental grounds. Human rights organization now are key actors globally, and we have not examined the procedures they must follow to be granted legitimacy. Truth Commissions raise important procedural issues fundamental to their success and legitimacy. There is now also a "rule of law» industry using the World Bank and many other entities to promote judicial training and reform. These efforts are so far studied and evaluated only by a few activist organizations. Who can assess the various experiences, relate it more generally to the times and 
places, and produce key models? We could multiply these examples, including mentioning the importance of procedures for making rules. My point is simply that procedural scholars have numerous domains outside of their traditional ones that invite systematic scholarly inquiry.

Why should we focus on these areas? One reason is simply that we are following the dictates of Klein, Cappelletti and others that procedural law should find a way to relate to new national and global movements. More fundamentally, perhaps, procedure is a key to law's fairness and ultimately its legitimacy. Procedural law is essential to all law. Many actors for their own reasons are using law and procedures for various ends, but they have neither the interest nor the expertise to explore systematically questions of standing, groups versus indivuals, formalism vs. informlism, acces, equality of arms, publicity (in the European sense), the quality of decision making, and the link to existing and historical state models. Procedural values evolve, but the point here is that they ought to be taken seriously and debated by those who best understand them. For procedure to keep the society in movement, in other words, comparative civil proceduralists will have to invest in new domains and reinvent the field. That does not mean that the old problems should be forgotten, but, as Mauro Cappelletti suggested, the domain has to be expanded.

The challenge is for comparative proceduralists to explore these new issues and domains. In the spirit of encouraging some U.S. -style entrepreneurial innovation in a more European context, therefore, I would like to make a suggestion for the international Association of Procedural Law. A modest step might be to devote some portion of the program of the meetings to sessions, ideas, and studies that are not necessarily preprogrammed. The idea would be to give a voice, perhaps, to some scholars who are outside of the mainstream but may be stretching the boundaries of comparative civil procedure. We could see what they have to say and use them to build and maintain a place for this organization and its scholars in bringing procedural learning to fundamental new social developments.

I recognize that I am suggesting a dose of U.S. openness and competition. Because of my own background, I tend to bring a mix of faith in, and skepticism about, the U.S. approaches that are part of me. I do think, however, that we are at a crossroads where we in the field of civil procedure eventually will either celebrate our marginality or find 
new ways to get involved with the «great intellectual movements of people». It takes hard work - harder than in the periods when Klein and Cappelletti produced their work. There is much in today's procedural scholarship that does exactly what I think I have found in the KleinCappelletti mandate. That is not surprising, but it may not hurt to remind us of our task, and challenge, for procedural scholarship on the threshold of a new millennium. 